CIVICS EDUCATION AND SOCIAL SCIENSE JOURNAL(CESSJ)

Volume 2 Nomor 2 Edisi Bulan Desember 2020

\title{
PENERAPAN METODE JIGSAW DENGAN BERBASIS TEKNOLOGI INFORMASI UNTUK MENINGKATKAN PRESTASI BELAJAR PKn BAGI SISWA KELAS XI SEMESTER 2 SMA NEGERI 3 SUKOHARJO TAHUN PELAJARAN 2014/2015
}

\author{
Penulis \\ Drs. Suwardi, M.H. \\ Guru PKn SMA Negeri 3 Sukoharjo \\ Email: suwardi_62@gmail.com
}

\begin{abstract}
ABSTRAK
Tujuan penelitian ini ialah untuk meningkatkan pembelajaran Pendidikan Kewarganegaraan bagi siswa kelas XI semester 2 SMA Negeri 3 Sukoharjo dan untuk meningkatkan minat belajar siswa pada mata pelajaran Pendidikan Kewarganegaraan bagi siswa kelas XI semester 2 SMA Negeri 3 Sukoharjo. Prosedur penelitian ini penelitian tindakan kelas yang dilaksanakan dalam dua siklus dengan melihat kondisi awal dengan satu stardar Kompetensi. Metode pengumpulan data dengan pengamatan dan nilai tes.Analisis data terdiri atas analisis deskriptif kualitatif dengan membandingkan siklus I dan siklus II. Serta analisis deskriptif komparatif dengan membandingkan hasil ulangan tes siklus I dan hasil ulangan tes siklus II yang selanjutnya direfleksi.

Hasil penelitian menunjukan bahwa minat dan kreaktifitas belajar siswa meningkat pada setiap siklus, Kondisi awal yang pasif sebanyak 60\%, siswa yang tidak berani bertanya $75 \%$, Kreaktifitas belajar siswa masih rendah dengan presentasi 25\%. Pada siklus I menunjukan siswa yang pasif sebanyak $30 \%$, siswa yang tidak berani bertanya $35 \%$, kreatifitas belajar siswa agak tinggi sebesar $60 \%$ sedangkan pada siklus II siswa yang pasif tinggal sedikit 5\%, siswa yang tidak berani bertanya tinggal $7 \%$, kreaktif belajar siswa meningkat menjadi $80 \%$. Selanjutnya dalam refleksi hasil belajar PKn menunjukkan bahwa kondisi awal : nilai terendah 50, nilai tertinggi 70 nilai rerata 65 dan rentang nilai 20 ulangan harian pada siklus I : nilai terendah 55, nilai tertinggi 82 dan nilai rata-rata 69 , rentang nilai 27 sedangkan kalau dibandingkan ulangan harian pada siklus II :nilai terendah 68, nilai tertinggi 100 dan nilai rerata 85, rentang nilai 32. Deskriptif komparatif dari kondisi awal dengan siklus I menunjukkan : nilai terendah meningkat $10 \%$ dari 50 menjadi 55, Nilai tertinggi meningkat $17 \%$ dari 70 menjadi 82 dan nilai rerata meningkat 6\% dari 65 menjadi 69. Deskriptif komparatif siklus I dengan siklus II menunjukkan : nilai terendah meningkat $24 \%$ dari 55 menjadi 68, Nilai tertinggi meningkat $22 \%$ dari 82 menjadi 100 dan Nilai rerata meningkat $23 \%$ dari 69 menjadi 85 . Disamping itu ada peningkatan pembelajaran dengan kreteria ketuntasan minimal Pkn 68, menggunakan metode Jigsaw dengan berbasis teknologi informasi siklus I ketuntasan mencapai 82,85\% dan pada siklus II mencapai ketuntasan $100 \%$.

Dengan demikian Penerapan metode jigsaw dengan berbasis teknologi informasi dapat meningkatkan prestasi belaja siswa.
\end{abstract}

Kata Kunci : Metode Jigsaw, teknologi informasi, dan Prestasi Belajar 


\title{
IMPLEMENTATION OF THE JIGSAW METHOD BASED ON INFORMATION TECHNOLOGY TO IMPROVE PKn LEARNING ACIEVEMENT FOR STUDENTS PKn CLASS XI SEMESTER 2 SMA NEGERI 3 SUKOHARJO LESSON YEAR 2014/2015
}

\author{
Author \\ Drs. Suwardi, M.H. \\ PKn Teacher \\ SMA Negeri 3 Sukoharjo \\ Email: suwardi_62@gmail.com
}

\begin{abstract}
The purpose of this study is to improve the Citizenship Education learning for class XI semester 2 students of SMA Negeri 3 Sukoharjo and to increase students' interest in learning in Citizenship Education subjects for class XI semester 2 SMA Negeri 3 Sukoharjo. The procedure of this research is classroom action research which is carried out in two cycles by looking at the initial conditions with one competency standard. Methods of data collection by observation and test scores. Data analysis consisted of qualitative descriptive analysis by comparing cycle I and cycle II. As well as a comparative descriptive analysis by comparing the results of the test repeat cycle I and the results of the test repeat cycle II which are then reflected.

The results showed that the students 'learning interest and creativity increased in each cycle, the initial condition was passive as much as $60 \%$, the students who did not dare to ask $75 \%$, the students' learning creativity was still low with a presentation of $25 \%$. In cycle I, it shows that students who are passive are $30 \%$, students who do not dare to ask questions are $35 \%$, student learning creativity is rather high by $60 \%$, while in cycle II students who are passive are only $5 \%$, students who do not dare to ask only $7 \%$, creative learning students increased to $80 \%$. Furthermore, in the reflection of Civics learning outcomes, it shows that the initial conditions: the lowest value is 50, the highest value is 70 , the average value is 65 and the value range is 20 daily tests in cycle I: the lowest value is 55 , the highest value is 82 and the average value is 69 , the value range is 27 whereas if compared to daily tests in cycle II: the lowest score was 68 , the highest score was 100 and the average value was 85 , the range of values was 32.The comparative descriptive of the initial conditions with the first cycle shows: the lowest score increased by $10 \%$ from 50 to 55 , the highest value increased $17 \%$ from 70 to 82 and the mean value increased $6 \%$ from 65 to 69 . The comparative descriptive cycle I to cycle II shows: the lowest value increased $24 \%$ from 55 to 68 , the highest value increased $22 \%$ from 82 to 100 and the mean value increased $23 \%$ from 69 to 85 . In addition, there is an increase in learning with Pkn 68 minimum completeness criteria, using the Jigsaw method based on the first cycle of information technology. completeness reached $82.85 \%$ and in cycle II reached $100 \%$ completeness.

Thus the application of the jigsaw method based on information technology can improve student achievement.
\end{abstract}

\section{Keywords: Jigsaw Method, Information Technology, and Learning Achievement}




\section{PENDAHULUAN}

Tujuan Negara Indonesia yang ketigaseperti yang diamanatkan didalam Pembukaan Undang-Undang Dasar 1945 didalam alinea keempat ialah "mencerdaskan kehidupan bangsa". Untuk mencerdaskan kehidupan bangsa dilaksanakan melalui penyelenggaraan pendidikan secara nasional. Menurut Undang-Undang Sisdiknas Nomer 20 tahun 2003 pengertian pendidikan adalah usaha sadar dan terencana untuk mewujudkan suasana belajar dan proses pembelajaran agar pesertadidik secra aktif mengembangkan potensi dirinya untuk memiliki kekuatan spiritual keagamaan, pengendalian diri kepribadian, kecerdasan akhlak mulia serta ketrampilan yang diperlukan dirinya, masyarakat dan Negara. (Sisdikkknas, $2003: 72$ ).

Menurut Undang-Undang Sisdiknas didalam pembelajaran harus terjadi proses interaksi peserta didik dan sumber belajar pada suatu lingkungan belajar ( Sisdiknas, 2004:74). Perintah dari Undang_Undang Sisdiknas agar terjadi proses interaksi dalam pembelajaran tersebut masih terdapat kendala didalam kelas. Kendalanya berasal dari peserta didik itu sendiri maupun dari guru yang mengajarnya.

Pada kenyataan Kondisi pembelajaran dilapangan menunjukkan bahwa peserta didik masih banyak yang kurang memperhatikan keterangan guru, hal ini antara lain : Siswa banyak yang ngantuk dikelas karena malam harinya melihat senetron di televisi, konsentrasi siswa mendua karena belum sarapan dari rumah sehingga mengingat - ingat kantin, Siswa bermain-main pakai HP, Siswa berbicara dengan siswa lain mengenai sesuatu hal diluar pelajaran yang sedang diikuti, Konsentrasi siswa kurang karena dipengaruhi kondisi rumah tangga yang kurang harmonis.

Kendala yang berasal dari seorang guru antara lain : metode pembelajaran yang digunakan seorang guru tidak melibatkan semua siswa, proses pembelajaran hanya didominasi dengan menggunakan metode ceramah saja, materi pelajaran tidak disusun secara sistematis berbentuk modul, guru tidak menggunakan media pembelajaran yang sesuai dengan pokok bahasan, guru mengajar asal mangajar tidak berpedoman pada Rencana Pelaksanaan Pembelajaran.

Berdasarkan fakta yang diuaraikan pendahuluan di atas permasalahan dalam penelitian ini dirumuskan: 1. Apakah melalui metode jigsaw dengan berbasis teknologi informasi dapat meningkatkan pembelajaran pendidikan Kewarganegaraan bagi siswa kelas XI semester 2 SMA Negeri 3 Sukoharjo tahun 2014//2015? Dan 2. Apakah melalui metode Jigsaw dengan berbasis teknologi informasi dapat meningkatkan minat belajar siswa pada mata pelajaran Pendidikan Kewarganegaraan, bagi siswa kelas XI semester 2 SMA Negeri 3 Sukoharjo tahun 2015/201?.

Berdasakan perumusan masalah seperti tersebut diatas, maka penelitian tindakan kelas ini bertujuan :1. Meningkatkan Hasil Belajar Pendidikan Kewarganegaraan bagi siswa kelas XI semester 2 SMA Negeri 3 Sukoharjo pada materi hubungan internasional 2. Meningkatkan minat belajar siswa pada mata pelajaran Pendidikan Kewarganegaraan bagi siswa kelas XI semester 2 SMA Negeri 3 Sukoharjo. 


\section{KAJIAN TEORI}

\section{Kajian Tentang Metode Jigsaw}

Mulyani Sumantri dan Johar Permana (2001:114) berpendapat bahwa metode merupakan cara-cara yang ditempuh untuk menciptakan situasi pembelajaran yang menyenangkan dan mendukung bagi kelancaram proses belajar dan tercapainya prestasi belajar siswa yang memuaskan. Sedangkan Syaiful Bahari Jamarah (2000 : 71) berpendapat bahwa metode adalah cara atau siasat yang digunakan dalam pembelajaran, metode pembelajaran adalah cara-cara yang efektif yang digunakan dalam proses belajar mengajar untuk mencapai tujuan mengajar, yaitu tujuan yang diharapkan tercapai oleh siswa dalam kegiatan belajar.

Menurut Oemar Hamalik (1989 : 100) secara teoritis metode mengajar dapat dibagi kedalam dua golongan, metode dalam kelas dan metode luar kelas. Metode ceramah merupakan metode mengajar dengan menyampaikan informasi dan pengetahuan secara lisan kepada sejumlah siswa dan siswa mengikuti secara pasif.

Metode diskusi merupakan salah satu metode belajar yang dapat diterapkan oleh guru di sekolah.Kegiatan diskusi melibatkan siswa untuk membicarakan dan menemukan alternatif pemecahan suatu topik bahasan yang bersifatd problematis.Guru, siswa, dan atau kelompok siswa memiliki perhatian yang sama terhadap topik yang dibicarakan dalam diskusi. Pada kegiatan diskusi terjadi interaksi antara dua atau lebih siswa.Siswa saling tukar menukar pengalaman, informasi dan memcahkan masalah.

Metode tanya jawab merupakan cara penyajian pelajaran dalam proses belajar mengajar melalui interaksi dua arah dari guru ke siswa atau dari siswa ke guru agar diperoleh jawaban tentang materi pelajaran melalui jawaban lisan guru atau siswa. Kegiatan tanya jawab dapat berfungsi untuk menyimpulkan atau kengikthtisarkan pelajaran yang telah dibaca siswa. Selaian itu kegiatan tanya jawab dapat digunakan untuk mengukur sejauh mana siswa menguasai materi yang telah dipelajari.

Guru diharapkan mampu membuat inovasi dalam metode pembelajaran untuk meningkatkan prestasi belajar, guru diharapkan mampu memilih dan menerapkan metode yang tepat dalam proses belajar mengajar yang disesuaikan dengan tujuan pembelajaran, materi yang akan disampaikan, situasi kelas serta disesuaikan dengan fasilitas yang tersedia disekolah. Salah satu diantaranya pembelajaran kooperatif.

Menurut pendapat Mohamad Nur (2005:5), terdapat tiga pembelajaran kooperatif yang cocok untuk hampir seluruh mata pelajaran dan tingkat kelas, yaitu: (a) metode student Teams Achievement Divisions (STAD); (b) Time Games Tournament (TGT); (c) Jigsaw. Salah satu pembelajaran kooperatif yang dapat digunakan untuk menyampaikan materi PKn adalah metode jigsaw. 
Ada beberapa langkah untuk menggunakan metode jigsaw, antara lain : (1) membagi siswa kedalam kelompok jigsaw, setiap kelompok terdiri dari lima sampai enam orang. Dalam satu kelompok terdiri dari siswa lakilaki dan perempuan, rasa yang berbeda, dan kemampuan yang beragam; (2) menugaskan satu siswa pada masing-masing kelompok sebagai pemimpin; (3) membagi materi pelajaran kealam lima sampai enam orang; (4) menugaskan masing-masing siswa untuk belajar satu topik; (5) siswa membaca topik yang diberikan guru; (6) siswa dari kelompok berbeda dengan topik yang sama bertemu membentuk "kelompok ahli". Siswa dalam kelompok ahli kembali pada kelompok jigsaw; (8) masing-masing siswa mengajikan topik yang telah dipelajari kepada kelompok jigsaw; (9) guru melakukan pengamatan. Bila ada kelompok yang mengalami gangguan (misalnya suatu anggota sedang mendominas atau mengganggu) pemimpin kelompok harus segara menegur siswa tersebut; (10) pada akhir kegiatan, siswa diberikan ulangan. (http://www.jigsaw.org/step.html.Jigsaw.in.10.Easy.Step,29Maret2011)

Menurut Mohamad Nur (2005:69) metode jigsaw terdiri dari siklus teratur kegiatan pengajaran, yaitu: (a) membaca; (b) diskusi kelompok ahli; (c) laporan tim; (d) kuis; (e) pernghargaan tim. Dalam melaksanakan setiap siklus, guru hendaknya merencanakan secara terstruktur waktu yang diperlukan pada masing-masing siklus.

Berkaiatan dengan penelitian ini, peneliti akan menggunakan metode jigsaw untuk meningkatkan prestasi belajar siswa kelas XI semester 2 tahun 2014/2015 SMA Negeri 3 Sukoharjo tahun . Menurut peneliti metode jigsaw mampu mengatasi budaya malas siswa dan meningkatkan keaktifan belajar siswa yang pada akhirnya dapat meningkatkan prestasi belajar siswa.

\section{Kajian Tentang Prestasi Belajar}

Kata "Prestasi" berasal dari bahasa Belanda yaitu "prestatie " yang berarti "hasil usaha", sedangkan dalam kamus besar bahasa Indonesia dijelaskan bahwa prestasi belajar merupakan penguasaan pengetahuan atau keterampilan yang dikembangkan oleh mata pelajaran yang lazimnya ditunjukkan dengan nilai tes atau angka nilai yang diberikan olch guru. Saifuddin Azwar (1999:13) berpendapat "Prestasi belajar adalah hasil yang telah dicapai oleh siswa dalam belajar". sedangkan dalam kamus besar bahasa Indonesia (Depdikbud, 1997:787), prestasi merupakan hasil yang telah dicapai.

Berdasarkan beberapa pendapat diatas dapat dijelaskan bahwa prestasi adalah hasil yang telah dicapai seseorang setelah melalui 
serangkaian kegiatan belajar.Prestasi belajar adalah basil yang telah dicapai seseorang dalam kegiatan belajar berupa suatu bentuk perubahan perilaku yang relatif menetap. (Cece Rakhmat dan Didi Suherdi , 2001:150)

\section{Kajian Tentang Pendidikan Kewarganegaraan (PKn)}

Dalam salah satu rumusan isi Pendidikan dalam ketetapan MPRS nomor XXVII/ MPRS/ 1968 BAB II pasal 4 menyatakan bahwa Pendidikan Kewarga Negaraan (PKN) merupakan suatu mata pelajaran yang menitikberatkan pada pembinaan watak semua anak-anak Indonesia agar kelak menjadi manusia dan warga negara yang ber-Pancasila dan bertaqwa kepada Tuhan Yang Maha Esa (Kurikulum 1968).

Berdasarkan Undang-Undang Republik Indonesia nomor 20 tahun 2003 tentang Sistem Pendidikan Nasional menyatakan bahwa mata pelajaran PKn memfokuskan pada pembentukan warga negara yang memahami dan mampu melaksanakan hak dan kewajiban untuk menjadi warga negara Indonesia yang cerdas, terampil dan sesuai amanat Pancasila dan UUD 1945.

a. Ruang Lingkup Mata Pelajaran pendidikan Kewarga Negaraan

Ruang lingkup mata pelajaran Penddikan Kewarga negaraan mulai SD/MI, SMP/MTs dan SMA/MA Berta SMAK meliputi aspek-aspek sebagai berikut:

a. Persatuan dan Kesatuan bangsa, merupakan rukun dalam perbedaan, Cinta lingkungan, Kebanggaan sebagai bangsa Indonesia, Sumpah Pemuda, Keutuhan Negara Kesatuan Republik Indonesia, Partisipasi dalam pembelaan negara, Sikap positif terhadap Negara Kesatuan Republik Indonesia, Keterbukaan dan jaminan keadilan;

b. Norma, hukum dan peraturan, meliputi: Tertib dalam kehidupan keluarga, Tata tertib di sekolah, Norma yang berlaku di masyarakat, peraturan-peraturan daerah, Norma-norma dalam kehidupan berbangsa dan bernegara, Sistirn hukum dan peradilan nasional, hukum dan peradilan internasional;

c. Hak asasi manusia meliputi: Hak dan kewajiban anak, Hak dan kewajiban anggota masyarakat, Instrumen nasional dan internasional HAM, Pemajuan, penghormatan dan perlindungan HAM;

d. kebutuhan warga negara meliputi: hidup gotong royong, harga diri sebagai warga masyarakat, Kebebasan berorganisasi, Kemerdekaan mengeluarkan pendapat, Menghargai keputusan bersama, Prestasi diri, Persamaan kedudukan warga negara; 
e. Konstitusi Negara meliputi: Proklamasi kemerclekaan dan konstitusi yang pertama,Konstitusi-konstitusi yang pernah digunakan di Indonesia, Hubungan dasar negara dengan konstitusi.

f. Kekuasan dan Politik, meliputi: Pemerintahan desa dan kecamatan, Pernerintalian daerah dan otonomi, Pemerintah pusat, Dernokrasi dan sistem politik, Budaya politik, Budaya demokrasi menuju masyarakat madani, Sistem pemerintahan, Pers dalam masyarakat demokrasi;

g. Pancasila meliputi: kedudukan Pancasila sebagai dasar negara dan ideologi negara, Proses perumusan Pancasila sebagai dasar negara, Pengamalan nilai-nilai Pancasila dalam kehidupan sehari-hari, Pancasila sebagai ideologi terbuka;

h. Globalisasi meliputi: Globalisasi di lingkungannya, Politik luar negeri Indonesia di era globalisasi, Dampak globalisasi, hubungan internasional dan organisasi internasional, dan merigevaluasi globalisasi. "Petunjuk Teknis Pengembangan Silabus Mata Pelajaran Pendidikan Kewarganegaman" diakses , 6 Maret 2011).

\section{Kerangka Pemikiran}

Peningkatan hasil belajartergantung pada banyak faktor diantaranya adalah faktor "input" dan "faktor "proses". Apabila input berkualitas, namun "proses" tidak mendukung, maka "output" nya belum tentu berkualitas pula, karena itu "proses" berperan penting dalam menghasilkan "output". Suatu permasalahan dalam "proses"adalah masalah metode penyampaian materi PKn. Metode yang masih konvensional dengan sistem ceramah dalam penyampaian materi memberikan dampak siswa kurang memahami konsep. Upaya penguatan pemahaman konsep dapat dilakukan dengan metode yang inovatif' yaitu dengan penggunaan metode jigsaw yang melibatkan siswa untuk lebih aktif dalam pembelajaran dengan diskusi kelompok. Hasil yang diharapkan dari metode tersebut adalah pemahaman konsep yang lebih kuat dan dampaknya "output" yang dihasilkan juga berkualitas sehingga tujuan peningkatan prestasi belajar siswa dapat tercapai.

Selanjutnya kerangka pemikiran dapat dilihat dengan bagan sebagai berikut : 


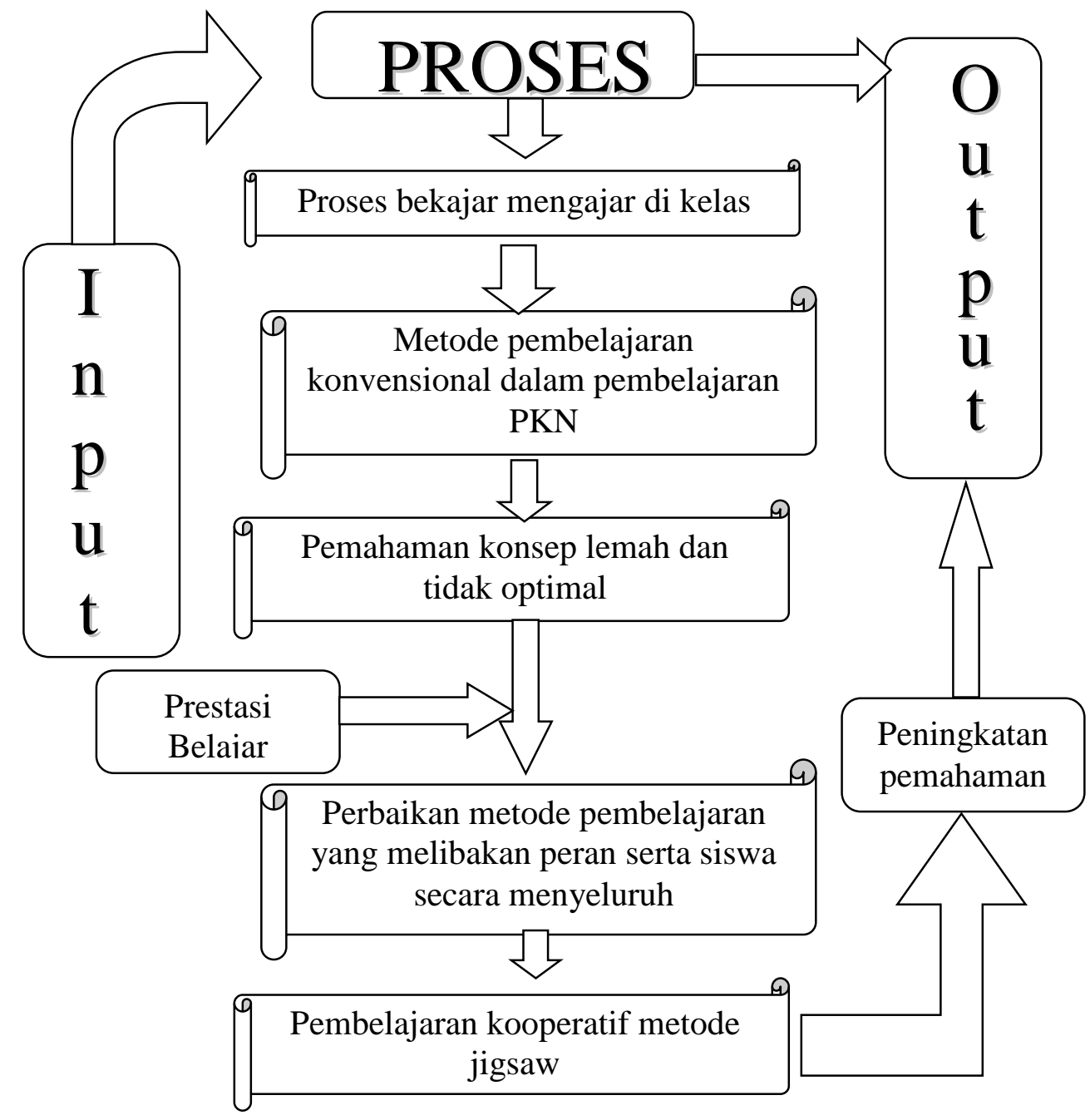

Dari kerangka berfikir tersebut dapat diajukan Hipotesis tindakan dalam penelitian ini sebagai berikut : 1. Mengajar dengan menggunakan metode jigsaw dapat meningkatkan pembelajaran pendidikan Kewarganegaraan bagi siswa kelas XI semester 2 SMA Negeri 3 Sukoharjo tahun 2014/2015 2. Mengajar dengan menggunakan metode Jigsaw dapat meningkatkan minat belajar siswa pada mata pelajaran Pendidikan Kewarganegaraan, bagi siswa kelas XI semester 2 SMA Negeri 3 Sukoharjo tahun 2014/2015

\section{METODE}

Metode yang digunakan dalam penelitian ini adalah Penelitian Tindakan Kelas, karena permasalahan yang dihadapi dirasakan oleh guru, peneliti, di kelas yang bertujuan untuk memecahkan masalah yang timbul dalam kelas dan untuk meningkatkan kualitas proses pembelajaran di kelas, maka jalan keluarnya dibuat berdasarkan kajian teori pembelajaran dan input dari lapangan. Disamping itu, pelaksanaan tindakan juga dilakukan oleh guru.

Untuk mengatasi hal tersebut maka diadakan suatu tindakan yang berupa penerapan pembelajaran kooperatif metode Jigsawuntuk meningkatkan 
prestasi belajar siswa. Dalam penerapan metode Jigsawdigunakan tindakan berulang atau siklus dalam setiap pembelajaran, artinya cara penerapan metode Jigsaw untuk peningkatan prestasi belajar siswa pada pembelajaran siklus 1, sama dengan yang diterapkan pada pembelajaran siklus II,

Refleksi terhadap setiap pembelajaran berbeda, tergantung dari fakta dan interpretasi data yang diperoleh atau situasi dan kondisi yang dijumpai. Hal ini dilakukan agar diperoleh hasil yang maksimal mengenai cara penggunaan metode Jigsaw untuk peningkatan prestasi belajar siswa. Berdasarkan tujuan penelitian, maka jelas bahwa penelitian ini, lebih bersifat mendiskripsikan data atau analisis kualitatif berdasarkan fakta dan keadaan yang ada disekolah. Variabel penelitian ini mencakup: ,1. variabel bebas yaitu Metode Pembelajaran Jigsaw dan 2. variabel terikat yaitu Prestasi Belajar PKn Siswa kelas XI Semester 2 SMA Negeri 3 Sukoharjo Tahun Pelajaran 2014/2015 Populasi dalam penelitian ini adalah semua siswa kelas XI Semester 2 SMA Negeri 3 Sukoharjo TahunPelajaran 2014 / 2015. Sampel penelitian ini adalah sebagian dari siswa kelas XI Semester 2 SMA Negeri 3 Sukoharjo tahun pelajaran 2014/2015 yang tertunjuk secara random dengan cara aundian. Samapel penelitian ini adalah kelas XI IPA 4. Metode pengumpulan data menggunakan : 1. Metode observasi, fungsi dari metode dan 2. Metode Tes digunakan untuk mengumpulkan data mengenai pencapaian prestasi belajar siswa kelas XIIPA 4 semester 2 SMA Negeri 3 Sukoharjo tahun pelajaran 2014/2015 yang tertunjikn sebagai sampel.

Teknik analisis yang digunakan dalam penelitian ini adalah deskriptif kualitatif. Hal ini dilakukan karena sebagian besar data yang dikumpulkan dalam penelitian ini berupa uraian deskriptif tentang perkembangan proses pembelajaran, yaitu penggunaan metode Jigsaw terhadap prestasi belajar siswa kelas XI Semester 2 SMA Negeri 3 Sukoharjo tahun pelajaran 2014/2015 dengan sampel Kelaas XI IPA-4.Deskriptif kualitatif, merupakan cara untuk mengelola dan menafsirkan data yang diperoleh sehingga dapat memberikan gambaran mengenai keadaan yang telah diteliti sesungguhnya. Prosedur penelitian adalah tata urutan yang dilakukan dalam penelitian tindakan kelas yang mencakup tahap-tahap:

1. Tahap Persiapan, yaitu: Mencari ijin penelitian kepada kepala sekolah SMA Negeri 3 Sukoharjo, Pengamatan supaya mendapatkan gambaran awal tentang keadaan siswa dengan mengetahuinilai semester satu ulangan harian 3 dan juga mengadakan tes awal. Mengadakan Identifikasi masalah dalam proses belajar mengajar PKn Yang telah dilaksanakan.

2. Tahap Perencanaan Tahap ini peneliti menyusun beberapa instrumen penelitian yang digunakan dalam tindakan dengan menggunakanmetode pembelajaran kooperatif Jigsaw.

3. Tahap Pelaksanaan dan Tindakan Pada tahap pelaksanaan tindakan pembelajaran kooperatif dengan menggunakan metode Jigsaw dilaksanakan dua siklus yaitu siklus I dan siklus II, dengan pelaksanaan tindakannnya seperti dibawah ini :

4. Tahap Observasi dan Evaluasi Pada tahap ini peneliti bertugas sebagi guru pengajar dan juga sebagai pengamat jalannya proses kegiatan belajar mengajar, pengamatan ini ditekankan pada penerapan pembelajaran kooperatif metode Jigsaw, terhadap prestasi belajar siswa yang dicapai.

5. Tahap Analisis dan Refleksi Pada tahap siklus I dilakukan analisis terhadap pelaksanaan proses Kegiatan Belajar Mengajar, dan hasil prestasi siswa dari 
materi yang telah dipelajari. Dari data yang diperoleh selanjutnya menjadi bahan relleksi bagi peneliti untuk perbaikan metode pembelajaran materi pokok berikutnya yaitu pada siklus II.

6. Tahap Tindak Lanjut Dari kegiatan penelitian diharapkan ada tindak lanjut dari guru ataupun peneliti dimaksudkan untuk melakukan perbaikan pembelajaran secara terus menerus serta mengembangkan metode pembelajaran agar kompetensi pembelajaran dapat tercapai dengan baik dan prestasi belajar siswa dapat maksimal sesuai dengan kemampuan yang dimiliki anak dan fasilitas sekolah yang tersedia.

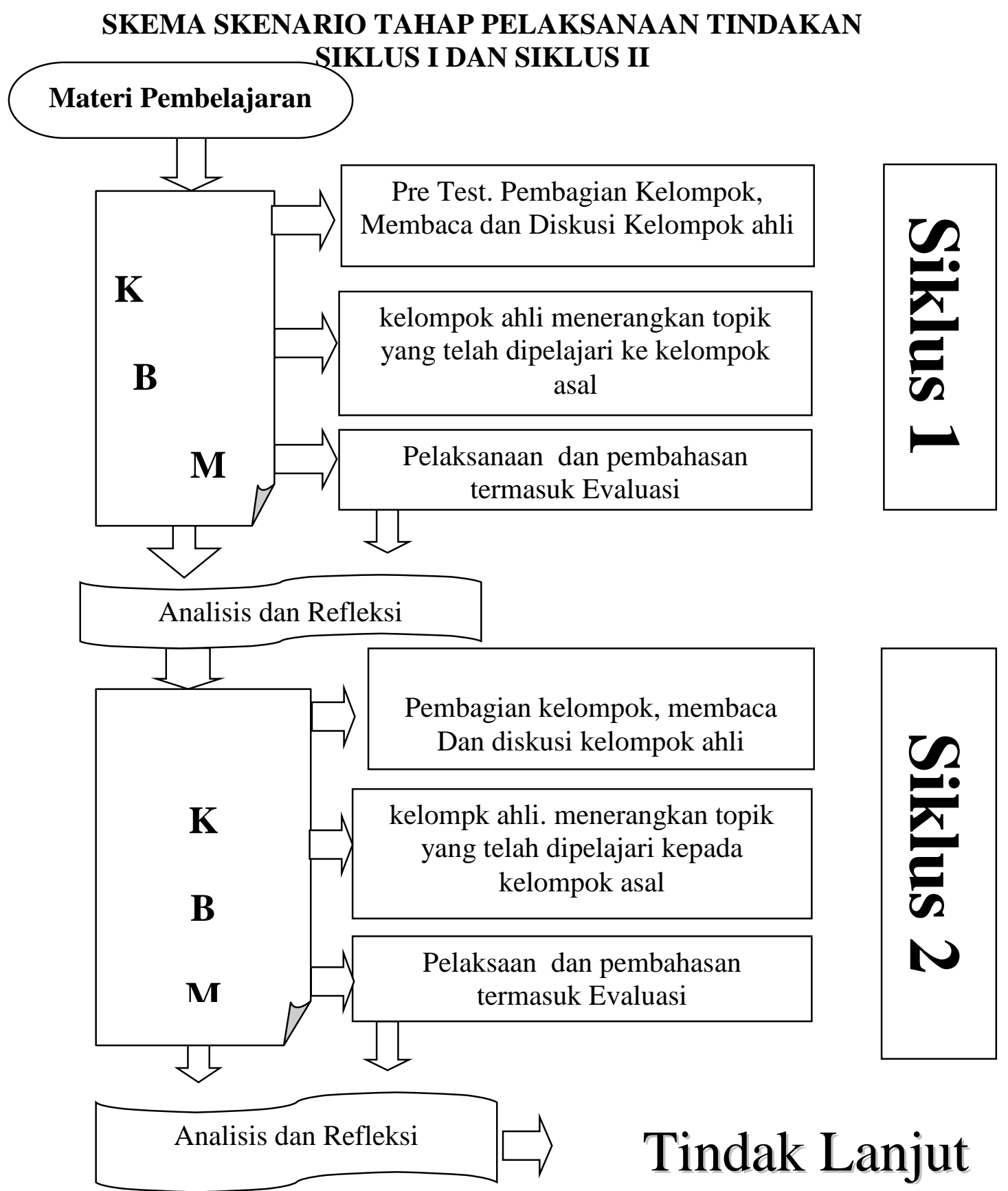

JORNAL PROGDI PPKn, FKIP UNIVET BANTARA SUKOHARJO BEKERJA SAMA DENGAN ASSOSIASI PROFESI PENDIDIKAN PANCASILA DAN KEWARGANEGARAAN (AP3KNI) JAWA TENGAH 


\section{HASIL PENELITIAN DAN PEMBAHASAN}

Penelitian ini secara garis besar dibagi menjadi 3 tahap, adapun ketiga tapan dalam penelitian ini adalah sebagai berikut: Tahap Persiapan dan Perijinan Pemikiran judulpenelitian tindakan kelas, pembuatan proposal, permohonan ijin penelitian. Tahap ini dilaksanakan pada bulan Januari 2015. Tahap Penelitian Meliputi semua kegiatan yang berlangsung di lapangan yaitu uji coba instrument dan pelaksanaan kegiatan pembelajaran di kelas.Tahap ini dilaksanakan pada bulan Februari sampai Maret 2015 Tahap Penyelesaian Meliputi analisis data yang telah terkumpul dan penyusunan laporan hasil penelitian pada bulan April 2015 sampai selesai.Untuk lebih jelasnya dapat dilihat pada tabel 1. Berikut ini :

\section{Deskripsi Kondisi Awal (Pra Tindakan)}

Berdasarkan pengamatan dan sebelum diterapkannya metode Jigsaw dengan berbasis teknologi informasi, dengan menggunakan metode tradisionalada beberapa hal yang menunujukan rendahnya motivasi siswa untuk belajar, kurang beranianya siswa untuk bertanya kepada teman, kurang beraninya siswa menjawab pertanyaan dari guru, dan kurang beraninya siswa menjawab pertanyaan yang diajukan oleh guru, maupun siswa, akibatnya interaksi antar siswa menjadi rendah interaksi dengan gurupun rendah pula. Hal ini dapat menghambat penyampaian materi pembelajaran yang pada akhimya akan mempengaruhi pencapaian prestasi belajar siswa secara maksimal.

Dengan mendasarkan nila PKn semester satu yang diambil dari nilai ulangan harian ke tiga dari kelas XI IPA 4 yang secara rondom tertunjuk sebagai sampel penelitian diperoleh bahwa tingkat pemahaman materi PKn masih rendah karena masih banyak siswa mendapatkan di bawah nilai tuntas yaitu 68.karena nilai KKM PKn 68. Identifikasi lebih lanjut terhadap metode pembelajaran yang digunakan guru masih menggunakan metode konvensional yaitu metode ceramah dimana siswa cenderung bersifat pasif karena siswa hanya sebagai pendengar. Di samping itu pembelajaran yang dilakukan masih selalu bersifat klasikal individual, sehingga interaksi antar siswa ketika proses pembelajaran berlangsung hamper tidak ada, karena guru hanya menghabiskan materi saja tanpa memperhatikan pembelajaran yang bermakna.

Kegiatan mengetahui kondisi awal siswa tentang hasil belajar siswa standar kompetensihubungan internasional dan organisasi internasional dilakukan secara klasikal individual dengan menggunakan Tes Awal. Hasil tes awal yang mengambarkan kondisi awal menunjukan sebagai berikut : 
CIVICS EDUCATION AND SOCIAL SCIENSE JOURNAL(CESSJ)

Volume 2 Nomor 2 Edisi Bulan Desember 2020

Tabel 1

Nilai Ulangan Harian Kondisi Awal

\begin{tabular}{|c|l|c|}
\hline \hline No. & \multicolumn{1}{|c|}{ Uraian } & Nilai UH \\
\hline 1 & Nilai terendah & 50 \\
\hline 2 & Nilai Tertinggi & 70 \\
\hline 3 & Nilai Rerata & 65 \\
\hline 4 & Rentang nilai & 20 \\
\hline
\end{tabular}

Dari Nilai tes awal menunjukan masih banyak anak yang tidak tuntas nilai tertinggi hanya 70, dari 35 siswa yang tuntas 3 anak atau 8,5\% masih jauh dari harapan dari KKM 68. Untuk meningkatkanprsetasi belajar siswa yang ditempuh oleh guru dalam hal ini juga sebagai peneliti dengan melakukan pembaharuan metode pembelajaran. Metode yang digunakan adalah metode komparatif Jigsaw dengan berbasis teknologi informasi dengan menggunakan dua siklus. Pelaksanaan pembelajaran dengan menggunakan metode jigsaw dengan berbasis teknologi informasi,.apabila siklus I dan hasil Refleksi dari siklus I masih ada yang kurang dilakukan tindak lanjut dengan langkah-langkah penyempurnaan pada siklus II. Metode pembelajaran yang diterapkan didalam siklus II sama dengan metode pembelajaran pada siklus I yaitu dengan metode Jigsaw sebagai metode komperatif.

\section{Perencanaan Tindakan I}

\section{Siklus I}

Sebagai perangkat pembelajaran, di dalam siklus I, peneliti menyiapkan silabus dengan menyusun rencana program pengajaran (RPP) mata pelajaran PKn, dengan standar kompetensi dasar 4.Menganalisis Hubungan Internasional dan Organisasi Internasional. Dengan Kompetensi dasar 4.1 mendeskripsikan pengertian, pentingnya dan sarana-sarana hubungan Internasional bagi suatu Negara. Dengan Materi Pengertian Hubungan Internasional, Dampak suatu Negara yang mengucilkan diri dari pergaulan antar bangsa, Pentingnya Hubungan Internasional dan Sarana-sarana hubungan Internasional.4.2 Menjelaskan Tahaptahap perjanjian Internasional. Dengan materi: Makna perjanjian Internasional, Istilah-istilah perjanjian Internasional, tahap-tahap perjanjian Internasional.Berkaitan dengan kegiatan belajar mengajar, peneliti menyiapkan beberapa masalah yang harus didiskusikan didalam kelompok dan tiap-tiap kelompok menerangkan kepada kelompok yang lain sehingga secara keseluruhan materi dapat dikuasai dan untuk terakhir sebelum diakhiri perajaran diadakan suatu kesimpulan. Untuk mengukur keberhasilan belajar siswa, peneliti membuat soal tes prestasi belajar siswa dengan kompetensi dasar yang telah didiskusikan dan harus dikerjakan setiap siswa sebagai hasil dari prestasi yang telah dipelajari. 
CIVICS EDUCATION AND SOCIAL SCIENSE JOURNAL(CESSJ)

Volume 2 Nomor 2 Edisi Bulan Desember 2020

\section{Pelaksanaan Tindakan I}

Pelaksanaan Tindakan I, peneliti menerapkan pembelajaran kooperatif metode Jigsaw dengan berbasis teknologi informasi . Pada pembelajaran ini guru menjelaskan tujuan pembelajaran yang akan dicapai dan metode pembelajaran yang digunakan dalam mengkaji materiKompetensi dasar 4.1 mendeskripsikan pengertian, pentingnya dan sarana-sarana hubungan Internasional bagi suatu Negara. Dengan Materi Pengertian Hubungan Internasional, Dampak suatu Negara yang mengucilkan diri dari pergaulan antar bangsa, Pentingnya Hubungan Internasional dan Sarana-sarana hubungan Internasional. 4.2 Menjelaskan Tahap-tahap perjanjian Internasional. Dengan materi: Makna perjanjian Internasional, Istilah-istilah perjanjian Internasional, tahap-tahap perjanjian Internasional.untuk siklus I. Kemudian peneliti membagi siswa kedalam kelompok dengan cara menghitung satu sampai lima sehingga ada delapan kelompok sebagai kelompok asal, disamping itu tiap kelompok disuruh menghitung urutan nomer satu sampai lima kemudian nomer satu berkumpul dengan nomer satu nomer dua berkumpul dengan nomer dua dan seterusnya sehingga ada lima kelompok sebagai kelompok ahli. Dari kelompok ahli diberi materi untuk dibahas dan didiskusikan setelah selesai pembahasan dari kelompok ahli tersebut kembali kekelompok asal dan kelompok ahli menerangkan didalam kelompok asal .selanjutnya setelah selesai disimpulkan bersama dengan guru. Metode Jigsaw dengan berbasis teknologi informasi dapat menjadikan siswa memiliki ketergantungan positif untuk saling membantu dalam penguasaan materi pelajaran karena dalam kegiatan pembelajaran kelompok dibuat heterogen sehingga didalam setiap kelompok siswa yang berkemampuan lebih akan membantu dalam proses pemahaman siswa yang berkemampuan rendah.Tugas guru melakukan pengamatan.Bila ada kelompok yang mengalami gangguan (misalnya suatu anggota sedang mendominasi atau mengganggu) guru memerintahkan kepada pemimpin kelompok untuk segera menegur siswa tersebut. Kegiatan terakhir, siswa diberikan ulangan untuk mengetahui hasil belajar siswa.

Tabel 2

Nilai Ulangan Harian Akhir Siklus 1

\begin{tabular}{|c|l|c|}
\hline \hline No. & \multicolumn{1}{|c|}{ uraian } & Nilai UH \\
\hline 1 & Nilai terendah & 55 \\
\hline 2 & Nilai Tertinggi & 82 \\
\hline 3 & Nilai Rerata & 69 \\
\hline 4 & Rentang nilai & 27 \\
\hline
\end{tabular}




\section{Observasi dan Evaluasi Tindakan I}

Dari hasil pengamatan yang dilakukan peneliti, diperoleh bahwa pada awal pembelajaran, siswa terlihat masih asing, (siswa kurang terlibat dalam pembelajaran atau kurang antusias).Disamping itu motivasi belajar siswa belum tampak, bahkan siswa masih banyak bergantung pada instruksi guru, dan belum menampakkan interaksi kelompok siswa.Namun setelah dilakukan perbaikan tindakan, pada tatap muka berikutnya siswa mulai terlihat antusias dan termotivasi untuk mengikuti pembelajaran dan interaksi dalam kerja kelompok pun mulai terlihat. Berdasarkan nilai KKM 68 maka siswa Kelas XI IPA 4 semester 2 SMA Negeri 3 Sukoharjo yang tuntas ada 29 siswa atau mencapai $83 \%$, sedangkan hasil evaluasi siklus I di peroleh siswa yang masih belum tuntas sebanyak 6 siswa atau yang tidak tuntas $17 \%$.

\section{Analisis dan Refleksi Tindakan I}

Didalam siklus I dibahas kompetensi dasar mendeskripsikan pengertian, pentingnya dan sarana-sarana Hubungan Internasional bagi suatu Negara,dan menjelaskan Tahap-tahap perjanjian Internasional,sebagai refleksi dan analisis tindakan I dapat peneliti sampaikan bahwa hasil siklus I menunjukan nilai terendah 55, nilai tertinggi 82, dan nilai rata-rata 69 , rentang nilai 27 . hal ini berbeda jauh kalau kita bandingkan dengan keadaan kondisi awal yang menunjukan bahwa nilai terendah 50. nilai tertinggi 70 , dan nilai rerata 65 , rentang nilai 20 , Untuk lebih jelas dapat dibuat keterangan dengan kolom sebagai berikut :

\section{Refleksi minat danKreaktivitas Belajar Pkn Siklus 1}

\begin{tabular}{|c|c|c|c|}
\hline No & Kondisi Awal & Siklus 1 & Refleksi \\
\hline 1. & $\begin{array}{l}\text { Masih banyak siswa } \\
\text { yang pasif dalam } \\
\text { menerima pelajaran } \\
\text { sebanyak } 60 \%\end{array}$ & $\begin{array}{l}\text { Siswa yang pasif dalam } \\
\text { menerima pelajaran } \\
\text { sudah mulai berkurang } \\
\text { sebanyak } 30 \%\end{array}$ & $\begin{array}{l}\text { Deskriptif kualitatif } \\
\text { siswa yang pasif } \\
\text { berkurang dari banyak } \\
60 \% \text { menjadi agak } \\
\text { banyak tinggal } 30 \%\end{array}$ \\
\hline 2. & $\begin{array}{l}\text { Siswa sebagian besar } \\
\text { tidak berani bertanya } \\
\text { dengan persentasi } 75 \%\end{array}$ & $\begin{array}{l}\text { Sebagian siswa tidak } \\
\text { berani bertanya dengan } \\
\text { presentasi } 35 \%\end{array}$ & $\begin{array}{l}\text { Untuk siswa yang } \\
\text { tidak berani bertanya } \\
\text { berkurang dari } \\
\text { sebagian besar atau } \\
75 \% \text { menjadi sebagian } \\
\text { atau menjadi } 35 \%\end{array}$ \\
\hline 3. & $\begin{array}{l}\text { Kreaktivitas siswa di } \\
\text { dalam belajar masih } \\
\text { rendah dengan } \\
\text { presentasi } 25 \%\end{array}$ & $\begin{array}{l}\text { Kreaktivitas siswa } \\
\text { dalam belajar agak } \\
\text { tinggi dengan presentasi } \\
60 \%\end{array}$ & $\begin{array}{l}\text { Kreaktivitas siswa } \\
\text { meninngkat } 25 \% \text { dari } \\
\text { rendah ke agak tinggi } \\
\text { dengan presentasi } \\
60 \%\end{array}$ \\
\hline
\end{tabular}




\section{Refleksi hasil belajar PKn pada siklus 1}

\begin{tabular}{|c|c|c|c|}
\hline No & Kondisi Awal & Siklus 1 & Refleksi \\
\hline 1. & $\begin{array}{l}\text { Ulangan harian pada } \\
\text { kondisi awal : } \\
\text { Nilai terendah } 50 \\
\text { Nilai tertinggi } 70 \\
\text { Nilai rerata } 65 \\
\text { Rentang nilai } 20\end{array}$ & $\begin{array}{l}\text { Ulangan Harian pada } \\
\text { Siklus } 1 \text { : } \\
\text { Nilai terendah } 55 \\
\text { Nilai tertinggi } 82 \\
\text { Nilai rerata } 69 \\
\text { Rentang nilai } 27\end{array}$ & $\begin{array}{l}\text { Deskriptif } \\
\text { komparatif nilai } \\
\text { terendah meningkat } \\
10 \% \text { dari } 50 \\
\text { menjadi } 55, \\
\text { Nilai tertinggi } \\
\text { meningkat } 17 \% \\
\text { dari } 70 \text { menjadi } 82 \\
\text { Nilai rerata } \\
\text { meningkat } 6 \% \text { dari } \\
65 \text { menjadi } 69\end{array}$ \\
\hline
\end{tabular}

Dari hasil analisis dan refleksi siklus I, ditemukan bahwa hasil pencapaian belajar siswa masih terdapat $17 \%$ atau 6 siswa yang belum tuntas.Untuk meningkatkan pemahaman siswa tentang materi yang telah dipelajari dilanjutkan pada siklus II.

\section{Perencanaan Tindakan II}

\section{Siklus II}

Sebagai perangkat pembelajaran, di dalam siklus II, peneliti menyiapkan silabus dengan menyusun rencana program pengajaran (RPP) mata pelajaran PKn, denganstandar kompetensi dasar 4.Menganalisis Hubungan Internasional dan Organisasi Internasional.Dengan Kompetensi dasar 4.3 Menganalisis fungsi perwakilan deplomatik. Dengan materi : pengertian perwakilan deplomatik, tingkatan perwakilan deplomatik, perwakilan konsuler, Fungsi perwakilan deplomatik. 4.4 mengkaji peranan organisasi internasional dalam meningkatkan hubungan internasional dengan materi :pengertian organisasi Internasional, macam-macam organisasi internasional, peranan dan tujuan PBB, Peranan dan tujuan ASEAN.Berkaitan dengan kegiatan belajar mengajar, peneliti menyiapkan beberapa maasalah yang harus didiskusikan didalam kelompok dan tiap-tiap kelompok menerangkan kepada kelompok yang lain sehingga secara keseluruhan materi dapat dikuasai dan untuk terakhir sebelum diakhiri pelajaran diadakan suatu kesimpulan. Untuk mengukur keberhasilan belajar siswa, peneliti membuat soal tes prestasi belajar siswa dengan kompetensi dasar 
yang telah didiskusikan dan harus dikerjakan setiap anak sebagai hasil dari prestasi yang telah dipelajari.

\section{Pelaksanaan Tindakan II}

Pelaksanaan Tindakan II, peneliti menerapkan pembelajaran kooperatif metode Jigsaw dengan berbasis teknologi informasi. Pada pembelajaran ini guru menjelaskan tujuan pembelajaran yang akan dicapai dan metode pembelajaran yang digunakan dalam mengkaji materi Kompetensi Dasar 4.3 Menganalisis fungsi perwakilan deplomatik Dengan Materi : pengertian perwakilan deplomatik, Tingkatan perwakilan deplomatik, perwakilan konsuler, Fungsi perwakilan deplomatik. 4.4 mengkaji peranan organisasi internasional dalam meningkatkan hubungan internasional dengan materi :pengertian organisasi Internasional, macam-macam organisasi internasional, peranan dan tujuan PBB, Peranan dan tujuan ASEAN,. untuk siklus II. Kemudian peneliti membagi siswa kedalam kelompok dengan cara menghitung satu sampai lima sehingga ada delapan kelompok sebagai kelompok asal, disamping itu tiap kelompok disuruh menghitung urutan nomer satu sampai lima kemudian nomer satu berkumpul dengan nomer satu nomer dua berkumpul dengan nomer dua dan seterusnya sehingga ada lima kelompok sebagai kelompok ahli. Dari kelompok ahli diberi materi untuk dibahas dan didiskusikan setelah selesai pembahasan dari kelompok ahli tersebut kembali kekelompok asal dan kelompok ahli menerangkan didalam kelompok asal .selanjutnya setelah selesai disimpulkan bersama dengan guru. Metode Jigsaw dengan berbasis teknologi informasi dapat menjadikan siswa memiliki ketergantungan positif untuk saling membantu dalam penguasaan materi pelajaran karena dalam kegiatan pembelajaran kelompok dibuat heterogen sehingga didalam setiap kelompok siswa yang berkemampuan lebih akan membantu dalam proses pemahaman siswa yang berkemampuanrendah.Tugas guru melakukan pengamatan.Bila ada kelompok yang mengalami gangguan (misalnya suatu anggota sedang mendominasi atau mengganggu) guru memerintahkan kepada pemimpin kelompok untuk segera menegur siswa tersebut. Kegiatan terakhir, siswa diberikan ulangan untuk mengetahui hasil belajar siswa. Observasi dan Evaluasi Tindakan II

Pada tindakan II subjek penelitian sudah menampakkan antusiasme dan motivasi belajar siswa yang tinggi.Hal ini tampak dari keberanian siswa untuk mengemukakan pendapatnya.Kerja kelompok juga menunjukkan interaksi yang efektif pada kegiatan diskusi siswa.Penerapan metode Jigsaw dengan berbasis teknologi informasi dapat memacu siswa untuk menyampaikan pendapat dan siswa lebih termotivasi untuk bersaing dengan kelompok yang lain. Persaingan dalam kelompok terjadi dalam hal mendapatkan 
penghargaan karena dalam, pembelajaran kooperatif Jigsaw dengan berbasis teknologi informasi terdapat penghargaan bagi kelompok yang berpestasi yang tidak terdapat dalam pembelajaran dengan metode lain termasuk dalam metode konvensional, sehingga hal ini akan membangkitkan motivasi belajar siswa untuk berprestasi melalui persaingan secara sehat. Adanya kegiatan kelompok akan memacu siswa untuk meraih prestasi yang tinggi karena didalam kelompokatau kerjasama terdapat segi-segi relasi, interaksi, partisipasi, dan kontribusi. Setiap siswa dalam pembelajaran Jigsaw dengan berbasis teknologi informasi berhubungan satusama lain, memberikan sumbangan pemikiran, saling mempengaruhi secara positif serta setiap siswa mempunyai tanggung jawab perseorangan dan terjadi komunikasi antar anggota sehingga suasana belajar menjadi dinamis.

Dari hasil penelitian, penerapan pembelajaran kooperatif metode Jigsaw dengan berbasis teknologi informasi pada siklus II dapat diketahui dari hasil belajar siswa serta kegiatan siswa selama diskusi. Pada siklus II siswa lebih tertarik mengikuti pelajaran karena siswa mulai terbiasa belajar dalam kelompok-kelompok dengan cara berdiskusi, - sehingga siswa dapat saling membantu mengerjakan tugas dari guru dan aktif dalam diskusi kelompok. Dengan demikian interaksi antara siswa dengan siswa dan antara siswa dengan guru dapat tejalin lebih baik daripada sebelumnya.

Pembelajaran jigsaw dengan berbasis teknologi informasi terjadi ketika siswa mempunyai tanggung jawab untuk mencapai tujuan bersama. Guru memegang peranan penting dalam menciptakan lingkungan yang mendukung aktivitas belajar siswa. Kerja kelompok dalam Jigsaw dengan berbasis teknologi informasi dapat membantu siswa meningkatkan pemahaman dan rasa senang serta memiliki sikap yang positif, baik terhadap kegiatan pembelajaran maupun terhadap diri sendiri.Keterampilan dalam berkelompok memberikan kesempatan kepada siswa untuk mengemukakan pendapat dan mendengarkan pendapat orang lain.

Peran guru di dalam kelas adalah mengelola komunikasi dan mengamati semua kegiatan siswa. Kerja sama dalam kelompok dapat memberikan suatu kesempatan belajar, dan berbagi tanggung jawab. Dalam kegiatan kelompok siswa dapat membagi tanggung jawab. Misalnya siswa dapat memeriksa berbagai materi sedangkan siswa lain mencatat hasilnya. Kerjasama dalam kelompok dapat melatih siswa bekeda secara mandiri.Pemecahan masalah dan negosiasi membantu siswa memecahkan konflik dan mengambil keputusan.Siswa dapat belajar dan berlatih menyelesaikan konflik berdasarkan pada keterampilan komunikasi yang baik dan sikap sabar.Adanya interaksi antar siswa dalam kelompok maupun interaksi antara siswa dengan guru membuat metode pembelajaran Jigsaw dapat meningkatkan prestasi belajar siswa. Hal tersebut dapat terjadi karena metode Jigsaw dengan berbasis teknologi informasi terdapat saling ketergantungan positif, komunikasi antar anggota dan adanya tatap muka yang merupakan 
unsur pokok dalam Jigsaw dengan berbasis teknologi informasi yang tidak ditemukan pada metode pembelajaran yang lain seperti pada metode ceramah Dari nilai ulangan Siklus II dapat diketahui :

Tabel 3

Nilai Ulangan Harian Akhir Siklus 2

\begin{tabular}{|c|l|c|}
\hline \hline \multirow{2}{*}{ No. } & \multicolumn{1}{|c|}{ Uraian } & Nilai UH 2 \\
\hline 1 & Nilai terendah & 68 \\
\hline 2 & Nilai Tertinggi & 100 \\
\hline 3 & Nilai Rerata & 85 \\
\hline 4 & Rentang nilai & 32 \\
\hline
\end{tabular}

\section{Analisis dan Refleksi Tindakan II}

\section{Refleksi minat dan Kreaktivitas Belajar Pkn Siklus 2}

\begin{tabular}{|c|c|c|c|}
\hline No & Siklus 1 & Siklus 2 & Refleksi \\
\hline 1. & $\begin{array}{l}\text { Siswa yang pasif } \\
\text { agak banyak dalam } \\
\text { menerima pelajaran } \\
\text { sudah berkurang } \\
\text { tinggal } 30 \%\end{array}$ & $\begin{array}{l}\text { Siswa yang pasif } \\
\text { dalam menerima } \\
\text { pelajaran tinggal } \\
\text { sedikit tinggal } \\
5 \%\end{array}$ & $\begin{array}{l}\text { Deskriptif kualitatif } \\
\text { siswa yang pasif } \\
\text { berkurang dari agak } \\
\text { banyak } 30 \% \text { menjadi } \\
\text { sedikit } 5 \%\end{array}$ \\
\hline 2. & $\begin{array}{l}\text { Sebagian siswa tidak } \\
\text { berani bertanya } \\
\text { dengan persentasi } 35 \\
\%\end{array}$ & $\begin{array}{l}\text { Sangat sedikit siswa } \\
\text { tidak berani bertanya } \\
\text { dengan persentasi } 7 \%\end{array}$ & $\begin{array}{l}\text { Siswa yang tidak } \\
\text { berani bertanya } \\
\text { berkurang dari } \\
\text { sebagian kecil } 35 \% \\
\text { menjadi sangat sedikit } \\
7 \%\end{array}$ \\
\hline 3. & $\begin{array}{l}\text { Kreaktivitas siswa di } \\
\text { dalam belajar agak } \\
\text { tinggi dengan } \\
\text { persentasi } 60 \%\end{array}$ & $\begin{array}{l}\text { Kreaktivitas siswa } \\
\text { dalam belajar tinggi } \\
\text { dengan persentasi } \\
80 \%\end{array}$ & $\begin{array}{l}\text { Kreaktivitas siswa } \\
\text { dalam belajar } \\
\text { meninngkat dari agak } \\
\text { tinggi } 60 \% \text { menjadi } \\
\text { tinggi } 80 \%\end{array}$ \\
\hline
\end{tabular}




\section{Refleksi hasil belajar PKn pada siklus 2}

\begin{tabular}{|c|c|c|c|}
\hline No & Siklus 1 & Siklus 2 & Refleksi \\
\hline 1. & $\begin{array}{l}\text { Ulangan harian pada } \\
\text { siklus1 : } \\
\text { Nilai terendah } 55 \\
\text { Nilai tertinggi } 82 \\
\text { Nilai rerata } 69 \\
\text { Rentang nilai } 27\end{array}$ & $\begin{array}{l}\text { Ulangan Harian } \\
\text { pada Siklus } 2: \\
\text { Nilai terendah } 68 \\
\text { Nilai tertinggi } 100 \\
\text { Nilai rerata } 85 \\
\text { Rentang nilai } 32\end{array}$ & $\begin{array}{l}\text { Deskriptif komparatif } \\
\text { nilai terendah } \\
\text { meningkat } 24 \% \text { dari } \\
55 \text { menjadi } 68 \\
\text { Nilai tertinggi } \\
\text { meningkat } 22 \% \text { dari } \\
82 \text { menjadi } 100 \\
\text { Nilai rerata meningkat } \\
23 \% \text { dari } 69 \text { menjadi } \\
85\end{array}$ \\
\hline
\end{tabular}

\section{Kesimpulan tindakan II}

Berdasarkan repleksi hasil belajar PKn pada siklus 2 terdapat peningkatan nilai dari nilai rata-rata meningkat $23 \%$, nilai tertinggi meningkat $22 \%$ dan nilai terendah meningkat $24 \%$. Disamping itu kalau kita bandingkan dengan kondisi awal, siklus 1 dan siklus 2 juga terdapat suatu peningakatan yang berarti. Untuk itu dapat disimpulkan :

a. Melalui metode jigsaw dengan berbasis teknologi informasi dapat meningkatkan pembelajaran pendidikan Kewarganegaraan bagi siswa kelas XI semester 2 SMA Negeri 3 Sukoharjo tahun 2014/2015. Untuk itu Hipotesis tindakan yang peneliti ajukan terbukti yaitu : Mengajar dengan menggunakan metode jigsaw dengan berbasis teknologi informasi dapat meningkatkan pembelajaran pendidikan Kewarganegaraan bagi siswa kelas XI semester 2 SMA Negeri 3 Sukoharjo tahun 2014/2015.

b. Melalui metode Jigsaw dengan berbasis teknologi informasi dapat meningkatkan minat belajar siswa pada mata pelajaran Pendidikan Kewarganegaraan, bagi siswa kelas XI semester 2 SMA Negeri 3 Sukoharjo tahun 2014/2015. Untuk itu hipotesis tindakan yang peneliti ajukan terbukti yaitu Mengajar dengan menggunakan metode Jigsaw dengan berbasis teknologi informasi dapat meningkatkan minat belajar siswa pada mata pelajaran Pendidikan Kewarganegaraan, bagi siswa kelas XI semester 2 SMA Negeri 3 Sukoharjo tahun 2014/2015.

\section{SIMPULAN}

Berdasarkan uraian dalam bab terdahulu dan hasil penerapan pembelajaran kooperatif metode Jigsaw dengan berbasis teknologi informasi pada proses pembelajaran siklus I dan siklus II dapat disimpulkan 
CIVICS EDUCATION AND SOCIAL SCIENSE JOURNAL(CESSJ)

Volume 2 Nomor 2 Edisi Bulan Desember 2020

bahwa pembelajaran kooperatif metode Jigsaw dengan berbasis teknologi informasi dapat $: 1$. Meningkatkan pembelajaran pendidikan kewarganegaraan bagi siswa kelas XI Semester 2 SMA Negeri 3 Sukoharjo tahun 2014/2015 2. Meningkatkan prestasi belajar dan minat belajar siswa pada mata pelajaran pendidikan kewarganegaraan bagi siswa kelas XI SMA negeri 3 Sukoharjo tahun 2014/2015

\section{REFERENSI}

Agus Supriyanto. 2009. Cooperative Leanning Teori dan Aplikasi Paikem, Yogyakarta : Pustaka Pelajar.

Anonim.Jigsaw.http://www.jigsaw.org/.Diakses tanggal 29 Maret 2011. .

Anonim.Jigsaw in 10 Easy Steps http://wwwjigsaw.org/steps.htm.diakses tanggal 29 Maret 2011.

Mulyani Sumantri,\& Johar Permana. 2001. Strategi Belajar Mengajar. Bandung: CV Maulana.

Mulyadi, H., HP. 2010, Makalah Penelitian Tidakan Kelas.Semarang : Departemen Pendidikan NasionalDirjen Peningkatan Mutu pendidikan dan tenaga kependidikan lembaga penjamin mutu pendidikan Jawa Tengah.

Mohamad Nur. 2005. Pembelajaran Kooperatif. Surabaya: Pusat Sains dan Matematika Sekolah UNESA.

Muhamad Nur \& Prima Retno Wikandari.2004. Pengajaran Berpusat Kepada Siswa dan Pendekatan Konstruktivisme dalam Pengajaran.Surabaya: Pusat Sain dan Matematika Sekolah UNESA.

Nuhadi. 2004. Kurikulum 2004. Jakarta: Gramedia Widiasarana.

Rustam Mundilarto. 2004. Penelitian Tindakan Kelas. Jakarta : direktorat Pembinaan Pendidikan dan ketenagaan Perguruan Tinggi. Depertemen Pendidikan Nasional

Saifuddin Azwar. 2000. Tes Prestasi Fungsi dan Pengembangan Pengukuran Prestasi Belajar Edisi ke-2. Yogyakarta: Pustaka Pelajar

Suhardjono, dkk. 2011. Publikasi Ilmiah. Batu : Cakrawala Indonesia. 